\title{
Acute Phase Proteins in Staphylococcus aureus Positive Milks
}

\author{
Sena Çenesiz ${ }^{1}$, Hande Gürler ${ }^{2}$, Arzu Fındık², Gülay Çiftci' ${ }^{1}$ Ali Ertekin ${ }^{1}$, Metin Çenesiz ${ }^{4}$ \\ Ondokuz Mayis University, Faculty of Veterinary Medicine, Departments of ${ }^{1}$ Biochemistry, ${ }^{2}$ Obstetrics, Gynaecology, \\ ${ }^{3}$ Microbiology and ${ }^{4}$ Physiology, Samsun, TURKEY
}

Geliş Tarihi / Received: 04.09.2018, Kabul Tarihi / Accepted: 13.10.2018

\begin{abstract}
In this study, acute phase proteins including haptoglobin, serum amyloid A, fibrinogen, albumin and total protein levels were investigated in cows with Staphylococcus aureus (S. aureus) positive subclinical mastitis. Healthy Jersey cows in lactation constituted the animal materials of the study. CMT test were applied to detect subclinical mastitis. In 21 milk samples collected from cows with subclinical mastitis, S. aureus was identified by PCR after bacteriologic isolation. These milk samples formed the study group. Healthy milks in which no bacteriological growth was observed were used as the control group. Elevations in haptoglobin (Hp) and serum amyloid A (SAA) levels in infected milk group compared to control milk group were statistically determined as $p<0,05$. Although an increase was observed in fibrinogen $(\mathrm{Fb})$, total protein $(\mathrm{TP})$ and albumin $(\mathrm{Alb})$ levels, the variations were not statistically significant.

In conclusion, in infected milks, total protein elevation is an expected result due to the presence of somatic cell and bacteria. In the present study, an increase was determined in total protein level, but it had no statistical significance. However, a significant increase was determined regarding haptoglobin and serum amyloid A in infected milk samples. This suggests that haptoglobin and serum amyloid A are more sensitive indicators in subclinical mastitis and may be beneficial in clinical practice.
\end{abstract}

Keywords: Acute phase proteins, Cows, Subclinical mastitis and S. aureus

\section{Staphylococcus aureus Pozitif Sütlerde Akut Faz Proteinleri}

\begin{abstract}
Özet: Bu çalışmada, Staphylococcus aureus pozitif subklinik mastitisli ineklerde, haptoglobin, serum amiloid A, fibrinojen, albümin ve toplam protein düzeylerini içeren akut faz proteinlerin düzeyleri araştırılmıştır. Laktasyonda Sağlıklı Jersey inekleri çalışmanın hayvan materyallerini oluşturdu. Subklinik mastitisi belirlemek için CMT testi uygulandı. Subklinik mastitisli ineklerden toplanan 21 süt örneğinde, $S$. aureus bakteriyolojik izolasyondan sonra PCR ile tanımlandı. Bu süt örnekleri çalışma grubunu oluşturdu. Kontrol grubu olarak bakteriyolojik büyümenin gözlenmediği sağlıklı sütler kullanıldı. Enfekte olmuş süt grubunda haptoglobin (Hp) ve serum amiloid A (SAA) düzeylerindeki artışlar kontrol sütüne göre istatistiksel olarak anlamlı bulundu $(\mathrm{p}<0,05)$. Fibrinojen $(\mathrm{Fb})$, total protein $(\mathrm{TP})$ ve albümin (Alb) düzeylerinde artış gözlenmesine rağmen, istatistiksel olarak bu artışın anlamlı olmadığı belirlendi. Bu sonuçlar, haptoglobulin ve serum amiloid A düzeyinin subklinik mastitisin belirlenmesinde daha duyarlı belirleyiciler olduğu ve klinik uygulamada yararlı olabileceğini düşündürmektedir.
\end{abstract}

Anahtar Kelimeler: Akut faz proteinleri, İnek, Subklinik mastitis ve S. aureus

\section{Introduction}

Mastitis is an inflammatory response against physiological and metabolic changes in mammary tissues, trauma and microorganisms [4]. The disease decreases milk yield and changes milk composition [22]. Subclinical mastitis is more significant due to its prevalence and economic losses because of the decrease in milk yield compared to clinical mastitis [13]. In subclinical mastitis no visible inflammation in the tits or changes in the milk are present, but milk yield and quality decreases [27]. Staphylococci are the most prevalent pathogens in subclinical and clinical mastitis and S. aureus is in the first rank among Staphylococcus spp. [19]. S. aureus decreases the milk yield and damages mammary tissue in milk cows, thus it prevents reaching potentially maximum milk level. In addition, this microorganism has a rapid adaptation feature against mastitis control programs and environmental changes [18].

The biochemical, hormonal, physiological and immunological responses of the organism against stimulants such as infection, burns, trauma and neoplasms in case of maintaining homeostasis is named as acute phase response (APR) [35]. Acute phase proteins are (APP) synthesized by the liver as a reaction to acute phase response. In healthy animals, 
these proteins are present in insignificant levels, but they rapidly increase during inflammation and plays role as an inflammation indicator. APP which is the specific indicator of tissue damage is gradually more widely used in veterinary medicine for the diagnosis, differential diagnosis, determination of prognosis, determination of therapeutic efficiency and herd therapy control $[6,8,17,31]$. Albumin (Alb) is accepted as the negative acute phase protein due to its small amount of synthesis during acute phase response where haptoglobin (Hp), serum amyloid A (SAA) and fibrinogen $(\mathrm{Fb})$ are the positive acute phase proteins due to their increased synthesis. Because some APP is specific to species, its diagnostic importance varies according to animal species. Hp, $\mathrm{SAA}, \mathrm{Fb}$ and Alb have high sensitivity in cows and are important acute phase proteins used during the course of inflammatory diseases [16,17,26,]. Eckersall [10] have reported that APP is also synthesized in mammary glands in addition to liver. This suggests that APP may be beneficial in the identification of mastitis.

The diagnosis of mastitis is performed by the clinical, chemical, physical, cellular and bacteriological examinations of the udder and milk. Absence of changes in clinical examination at milk and udder in subclinical mastitis requires the usage of specific diagnostic methods. In this study, benefits of APP in the diagnosis, identification, determination of therapy and therapeutic efficiency of subclinical mastitis was aimed.

\section{Materials and Methods}

\section{Milk samples}

Materials of the study included 21 milk samples from clinically healthy Jersey cows in lactation, aged between 2-10 years housed in a private farm in Samsun region.

This study was approved by the Ondokuz Mayis University Ethics Committee. Animals in which no clinical findings were observed in nipple examinations were evaluated with respect to subclinical mastitis. For this purpose, California mastitis test (CMT) and electrical conductivity measurement by a portable electrical conductivity meter were applied to milk samples obtained from each animal just before milking. Data about electrical conductivity were recorded and approximately $20 \mathrm{ml}$ of milk found CMT positive were sampled aseptically from each teat and then transferred to the laboratory under cold chain. CMT negative milks of the healthy cows were used as the control group.

\section{Bacterial identification}

Milk samples transferred to the laboratory under cold chain were inoculated onto $5 \%$ sheep blood agar following vortexing and homogenization. Petri dishes were incubated at $37^{\circ} \mathrm{C}$ for $24-48$ hours. After incubation period, $S$. aureus suspected colonies were identified morphologically, microscopically and biochemically [32]. PCR from culture was performed for the confirmation of the identification. Protocol done by Abd El-Razik et al. [2] was used for identification by PCR following DNA extraction. Mastitic milk samples from which were isolated $S$. aureus were included in the study to be examined for other specifications.

\section{Determination of acute phase proteins}

All milk samples were placed in tubes and centrifuged $\left(1550 \mathrm{~g}, 10 \mathrm{~min},+4{ }^{\circ} \mathrm{C}\right)$. Milk samples were defatted before use. The separated serum samples were then stored at $-80{ }^{\circ} \mathrm{C}$ until analyzed. Acute phase proteins were determined and evaluated in mastitis ( $S$. aureus) positive and control animals. Milk serum concentration of Hp was measured according to enzyme-linked immunosorbent assay (ELISA) procedure by a commercially available ELISA kit (Tridelta Development Ltd., Ireland). SAA was measured by a solid-phase sandwich enzyme-linked immunosorbent assay (ELISA) by a commercially available ELISA kit (Phase SAA kit, Tridelta Ltd., Ireland). Milk serum concentrations of $\mathrm{Fb}$ detected by a commercially available kit (Cusabio Biotech Co., Ltd., China). A Digital and Analogue Systems (Italy) ELISA microplate reader (digital and analog systems Roma, Italy) was used.

Milk serum concentrations of total protein and albumin were analyzed using a commercially available kit (Sigma-Aldrich Chemie $\mathrm{GmbH}$, Eschenstraße 5, 82024 Taufkirchen, Germany) according to the autoanalyser manufacturer's instruction (Autolab, AMS Srl, Selective Access). 


\section{Statistical Evaluation}

One Way Anova test for two independent samples was used for statistical comparison between experiment and control groups.

\section{Results}

Acute phase protein values of $S$. aureus positive milk samples evaluated for subclinical mastitis and the control groups were shown in Table 1 and 2.

Table 1. The comparison of mean \pm SD results for milk Haptoglobin (Hp), serum amyloid A (SAA), fibrinogen (Fb), Total Protein (TP) and Albumin (Alb) levels in control and S.aureus positive milk samples.

\begin{tabular}{lccc}
\hline & Control milk & S.aureus $(+)$ milk & P \\
\hline $\mathrm{Hp}(\mu \mathrm{g} / \mathrm{ml})$ & $0.32 \pm 0.01$ & $0.87 \pm 0.59$ & 0.001 \\
$\mathrm{SAA}(\mu \mathrm{g} / \mathrm{ml})$ & $31.81 \pm 19.69$ & $122.24 \pm 81.92$ & 0.049 \\
$\mathrm{Fb}(\mu \mathrm{g} / \mathrm{ml})$ & $6.65 \pm 0.11$ & $12.71 \pm 1.97$ & 0.066 \\
$\mathrm{TP}(\mathrm{g} / \mathrm{dl})$ & $27.33 \pm 3.09$ & $46.83 \pm 10.24$ & 0.135 \\
$\mathrm{Alb}(\mathrm{g} / \mathrm{dl})$ & $2.00 \pm 0.46$ & $3.24 \pm 0.65$ & 0.416 \\
\hline
\end{tabular}

Table 2. Haptoglobin (Hp), serum amyloid A (SAA), fibrinogen (Fb), Total Protein (TP) and Albumin (Alb) levels in milk the correlation between values

\begin{tabular}{lccccc}
\hline & Hp & SAA & Fb & TP & Alb \\
\hline Hp & 1 & 0.046 & 0.304 & $0.411^{*}$ & $0.536^{* *}$ \\
SAA & & 1 & 0.358 & 0.249 & 0.004 \\
Fb & & & 1 & $0.685^{* *}$ & $0.675^{* *}$ \\
TP & & & & 1 & $0.628^{* *}$ \\
Alb & & & & & 1 \\
\hline
\end{tabular}

$* \mathrm{P}<0.05 * * \mathrm{P}<0.01$

Acute phase protein values of the control group and $S$. aureus positive group were determined as $0.33 \mu \mathrm{g} / \mathrm{ml}$ and $2.41 \mu \mathrm{g} / \mathrm{ml}$ for $\mathrm{Hp}, 55.65 \mu \mathrm{g} / \mathrm{ml}$ and $292.87 \mu \mathrm{g} / \mathrm{ml}$ for SAA, $6.65 \mu \mathrm{g} / \mathrm{ml}$ and $13 \mu \mathrm{g} / \mathrm{ml}$ for $\mathrm{Fb}, 26.60 \mathrm{~g} / \mathrm{dl}$ and $48 \mathrm{~g} / \mathrm{dl}$ for TP, $2 \mathrm{~g} / \mathrm{dl}$ and $3.30 \mathrm{~g} /$ $\mathrm{dl}$ for Alb, respectively (Figure 1 and 2).

Elevation in $\mathrm{Hp}$ and SAA levels in infected milk group compared to control milk group was calculated as $\mathrm{p}<0.05$ statistically. Elevations in $\mathrm{Fb}, \mathrm{TP}$ and Alb were not statistically significant.

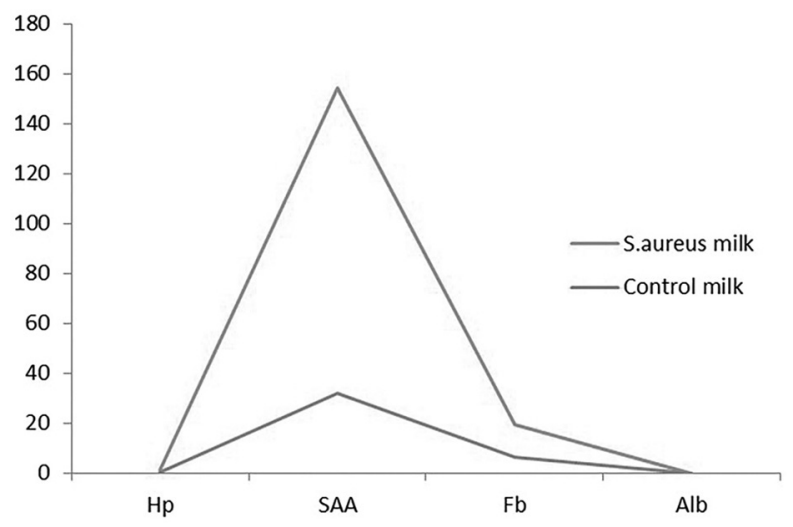

Figure 1. Haptoglobin (Hp), serum amyloid A (SAA), fibrinogen $(\mathrm{Fb})$ and Albumin (Alb) levels in control and S.aureus positive milk samples.

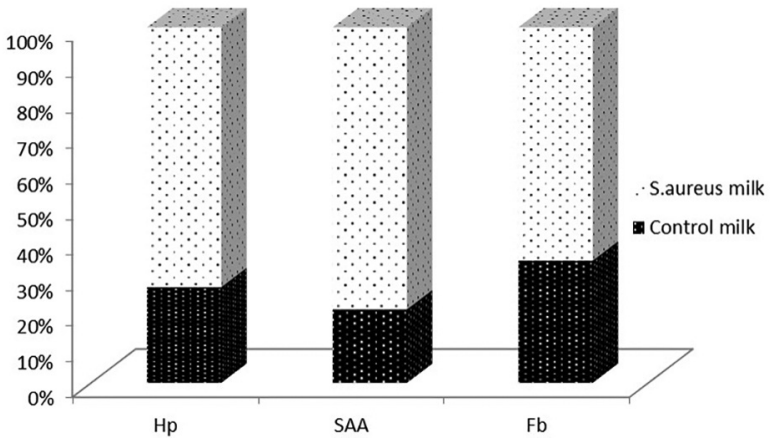

Figure 2. Percentage distribution of milk Haptoglobin (Hp), serum amyloid A (SAA), fibrinogen (Fb), levels among groups.

\section{Discussion}

Mastitis as a major factor effecting milk yield causes serious economic losses. Inflammatory signs and differentiation in milk are examined in clinical mastitis. Lack of these signs and visible variations in milk and teats causes a longer period of mastitis and this yields increased economic losses $[12,13$, 37]. Therefore, the development of new strategies to prevent or treat mastitis should remain a priority among animal health initiatives [12]. Efforts in research have been directed for searching a biomarker of subclinical mastitis, not only to identify affected animals but also to evaluate and to prevent alterations in milk quality [24]. More prevalent bacterial agent was reported as $S$. aureus in bovine subclinical mastitis [34]. In this study, S. aureus positive milks were preferred to investigate acute phase protein levels. 
Haemolysins are cytotoxic agents that damage and/or destroy cells of the defense system. Alphahaemolysin ( $\alpha$-toxin), frequently produced by bovine $S$. aureus IMI (Intra mammary infection) isolates, is toxic to bovine mammary cells $[1,3,5]$. When tissue is affected by microorganisms, first the pro-inflammatory cytokines are secreted. Especially Interleukin-6 (IL-6), tumor necrosis factor- $\alpha$ $(\mathrm{TNF}-\alpha)$ and Interleukin- $1 \beta$ (IL-1 $\beta$ ) provides APP secretion in liver as the mediator and yields an elevation of these proteins in blood [26,30]. Both SAA and $\mathrm{Hp}$ are among the major positive APPs in cattle and can increase several-fold from baseline levels after tissue injury [26, 31]. However, APPs such as SAA and Hp also were synthesized and secreted by the mammary tissue nearby liver [10, 20, 25].

Nazifi et al. [28] have determined an increase at $\mathrm{Hp}$ and SAA levels in cattle with clinical and subclinical mastitis compared to the control groups, but also they have reported that the increase in clinical mastitis was superior to that of subclinical mastitis. Colla et al. [7] similarly have reported an increase in $\mathrm{Hp}$ and $\mathrm{Fb}$ levels in cattle with subclinical mastitis and have stated that this may be an indicator in the early diagnosis of subclinical mastitis. Few previous studies have indicated that $\mathrm{Hp}$ and SAA may be used in the diagnosis of clinical mastitis in cattle $[9,15,21,29]$. The present study revealed similar results for Hp and SAA elevation with other studies. Tabrizi et al. [36] and Colla et al. [7] have found higher fibrinogen levels in cows with both clinical and subclinical mastitis regarding to healthy milks and have suggested that this may be beneficial in the diagnosis of mastitis. However, no elevation was observed in fibrinogen levels in the present study.

Albumin is accepted as negative acute phase protein due to its less synthesis by liver during acute phase response [17]. However, albumin is synthesized in mammary tissues and in mastitic milks, 3.5 fold albumin increase was reported compared to healthy milks. Normally albumin is accepted as a negative acute phase protein, but in case of mastitis an elevation may be observed [33]. In the present study, no statistically significant increase was recorded.

Plasma proteins are mainly synthesized by the liver. Analysis of total protein concentrations and percentage of protein fractions are important in var- ious disease states [23]. Milk protein content was higher in mastitic cow milks, probably due to the high amount of somatic cells and bacteria [14]. Besides, increase in bacteria and somatic cells nearby $\mathrm{Alb}$, suggests an increase in total protein levels and parameters such as SAA and HP. In our study, an increase was observed in total protein, but was not statistically significant.

In conclusion, in mastitic milks, an increase was expected in total protein due to the increase of bacteria, somatic cell, Fb, SAA, Hp and Alb levels. In our study, increase in total protein was observed which did not have a statistical value. Similarly, an increase was expected in albumin, which is normally accepted as a negative acute phase protein due to its synthesis in the mammary tissue, but no statistically significant increase was observed. Similar situation was also valid for $\mathrm{Fb}$, which was previously reported to increase. However, a statistical elevation was observed in only milk Hp and SAA among acute phase proteins. This suggests that these two parameters, Hp and SAA levels are more sensitive indicators in mastitis and in clinical practice and may have a diagnostic value for subclinical mastitis.

\section{References}

1. Aarestrup FM, Larsen HD, Eriksen NH, Elsberg CS, Jensen NE, (1999). Frequency of alpha- and beta-haemolysin in Staphylococcus aureus of bovine and human origin. A comparison between pheno- and genotype and variation in phenotypic expression. APMIS. 107, 425-430.

2. Abd El-razik A, Abdelrahman KA, Ahmed YF, Gomaa AM, Eldebaky HA, (2010). Direct identification of major pathogens of the bubaline subclinical mastitis in Egypt using PCR. J Amer Sci. 6, 652-660.

3. Akineden O, Annemuller C, Hassan AA, Lammler C, Wolter W, Zschöch M, (2001). Toxin genes and other characteristics of Staphylococcus aureus isolates from milk of cows with mastitis. Clin Diagn Lab Immunol. 8, 959-964.

4. Albenzio M, Taibi L, Muscio A, Sevi A, (2002). Prevalence and etiology of subclinical mastitis in intensively managed flocs and related changes in the yield and quality of ewe milk. Small Rumin Res. 43, 219-226.

5. Bramley AJ, Patel AH, Reilly MO, Foster R, Foster TJ, (1989). Roles of alpha-toxin and beta-toxin in virulence of Staphylococcus aureus for the mouse mammary gland. Infect Immun. 57, 2489-2494.

6. Ceron JJ, Eckersal PD, Martinez-subiela S, (2005). Acute phase proteins in dogs and cats: current knowledge and future perspective. Vet Clin Pathol. 34, 85-99. 
7. Colla MF, Valle SF, Secchi P, Duda N, Scalon M, Durr JW, Hilario F, González D, (2011). Plasma haptoglobin values in cows with different somatic cell counting in milk samples. Acta Sci Vet. 39, 944.

8. Eckersall PD, (2000). Recent advances and future prospects for the use of acute phase proteins as markers of disease in animals. Rev Med Vet. 151, 577-584.

9. Eckersall PD, Young FJ, Mccomb C, Hogarth CJ, Safi S, Weber A, Mcdonald T, Nolan AM, Fitzpatrick JL, (2001). Acute phase proteins in serum and milk from dairy cows with clinical mastitis. Vet Rec. 148, 35-41.

10. Eckersall PD, Young FJ, Nolan AM, Knight CH, Mccomb C, Waterston MM, Hogarth CJ, Scott EM, Fitzpatrick JL, (2006). Acute phase proteins in bovine milk in an experimental model of Staphylococcus aureus subclinical mastitis. J Dairy Sci. 89, 1488-1501.

11. El-deeb WM, (2013). Clinicobiochemical investigations of gangrenous mastitis in does: immunological responses and oxidative stress biomarker. J Zhejiang Univ Sci B. 14, 3339.

12. Fabres-Klein MH, Klein RC, De Paula SO, Ribon AOB, (2013). Immunorelevant proteins for the diagnosis of bovine staphylococcal mastitis. World J Microbiol Biotechnol. 29, 1155-1160.

13. Getaneh AM, Mekonnen SA, Hogeveen H, (2017). Stochastic bio-economic modeling of mastitis in Ethiopian dairy farms. Prev Vet Med. 138, 94-103.

14. Gill R, Howard WH, Leslie KE, Lissemore K, (1990). Economics of mastitis control. J Dairy Sci. 73, 3340-3348.

15. Gronlund U, Hulten C, Eckersall PD, Hogarth C, Waller KP, (2003). Haptoglobin and serum amyloid $A$ in milk and serum during acute and chronic experimentally induced Staphylococcus aureus mastitis. J Dairy Res. 70, 379-386.

16. Gruys E, Obwolo MJ, Toussaint M, (1994). Diagnostic significance of the major acute phase proteins in veterinary clinical chemistry: A Review. Vet Bull. 64, 1009-1018.

17. Gruys E, Toussaint MJM, Niewold TA, Koopmans SJ, (2005). Acute phase reaction and acute phase proteins. J Zhejiang Univ Sci B 11, 1045-1056.

18. Guidry A, Fattom A, Atul P, Oõbrien C, Shepherd S, Lohuis J, (1998). Serotyping scheme for Staphylococcus aureus isolated from cows with mastitis. Am J Vet Res. 59, 15371539.

19. Hadimli HH, Ates M, Guler L, Kav K, Oncel T, (2001). Some virulence factors and antibiotic sensitivity of Staphylococcal strains isolated from cows with subclinical mastitis. Vet Bil Derg. 17, 21-25.

20. Hiss S, Mielenz M, Bruckmaier RM, Sauerwein H, (2004). Haptoglobin concentrations in blood and milk after endotoxin challenge and quantification of mammary Hp $\mathrm{mRNA}$ expression. J Dairy Sci. 87, 3778-3784.

21. Hiss S, Mueller U, Neu-zahren A, Sauerwein H, (2007). Haptoglobin and lactate dehydrogenase measurements in milk for the identification of subclinically diseased udder quarters. Vet Med. 52, 245-252.

22. Janzen JJ, (1970). Economic losses resulting from mastitis. A review. J Dairy Sci. 53, 1151-1161.
23. Kaneko JJ, John W, Bruss HM, (2008). Clinical Biochemistry of Domestic Animals Gulf Academic press, sixth edition.

24. Korhonen H, Kaartinen L, (1995). Changes in the composition of milk induced by mastitis. In: Sandholm M., Honkanen- Buzalski T., Kaartinen L. \& Pyorala S. (Eds). The bovine udder and mastitis. Jyvaskila: Gummerus Kirjapaino, 76-82.

25. Mcdonald LT, Larson MA, Mack DR, Weber A, (2001). Elevated extrahepatic expression and secretion of mammary-associated serum amyloid A 3 (M-SAA3) into colostrum. Vet Immunol Immunopathol. 83, 203-211.

26. Murata H, Shimada N, Yoshioka M, (2004). Current research on acute phase proteins in veterinary diagnosis: an overview. Vet J. 168, 28-40.

27. Mutluer D, Hatipoğlu FŞ, Türütoğlu H, Özmen Ö, Oğuz N, Ata A, Alçi S, Köker A, Karakurum Ç, (2001). Mastitis oluşumu, tanısı ve sağaltımı. Süt İnekçiliğinde Mastitis Sempozyum Kitabı., 04-05 Mayıs, Akdeniz Üniversitesi, 27-38.

28. Nazifi S, Haghkhah M, Asadi Z, Ansari-lari M, Tabandeh MR, Esmailnezhad Z, Aghamiri M, (2011). Evaluation of sialic acid and acute phase proteins (haptoglobin and serum amyloid A) in clinical and subclinical bovine mastitis. Pakistan Vet J. 31, 55-59.

29. Nielsen BH, Jacobsen S, Andersen PH, Niewold TA, Heegaard PMH, (2004). Acute phase protein concentrations in serum and milk from healthy cows, cows with clinical mastitis and cows with extramammary inflammatory conditions. Vet Rec. 15, 361-365.

30. Nukina H, Sudo N, Aiba Y, Oyama N, Koga Y, Kubo C, (2001). Restraint stress elevates the plasma interleukin-6 levels in germ-free mice. J Neuroimmunol. 115, 46-52.

31. Petersen HH, Nielsen JP, Heegard PMH, (2004). Application of acute phase protein measurements in veterinary clinical chemistry. Vet Res. 35, 163-187.

32. Quinn PJ, Carter ME, Markey BK, Carter GR, (1994). Clinical Veterinary Microbiology. Mosby: U.K.

33. Shamay A, Homans R, Fuerman Y, Levin I, Barash H, Silanikove N, Mabjeesh SJ, (2005). Expression of Albumin in Nonhepatic Tissues and its Synthesis by the Bovine Mammary Gland. J Dairy Sci. 88, 69-76.

34. Shitandi A, Kihumbu G, (2004). Assessment of the California mastitis test usage in small holder dairy herds and risk of violative antimicrobial residues. J Vet Sci. 5 , 5-9.

35. Steel DM, Whithead AS, (1994). The major acute phase reactants: $C$-reactive protein, serum amyloid $P$ component and serum amyloid A protein. Immunol Today. 15, 81-88.

36. Tabrizi AD, Batavani RA, Rezaei SA, Ahmadi M. (2008). Fibrinogen and ceruloplasmin in plasma and milk from dairy cows with subclinical and clinical mastitis. Pakistan J Biol Sci. 11, 571-576.

37. Tel OY, Keskin O, Zonturlu AK, Arserim Kaya NB, (2009). Subclinical mastitis prevalance and determination of the antibiotics susceptibility in Sanliurfa region. Frrat Üniv Sağl Bil Vet Derg. 23, 101-106. 